\title{
Legitimacy and contestation in global governance: Revisiting the folk theory of international institutions
}

\author{
Ian Hurd ${ }^{1}$
}

Published online: 5 December 2018

(C) Springer Science+Business Media, LLC, part of Springer Nature 2019

Whether international institutions are seen as legitimate or not is important to whether they are able to exercise authority. An institution that is seen as legitimate finds it easier to gain acquiescence with its rules and decisions and so relies less on outright coercion. From the point of view of the organization therefore legitimacy is a useful property worth cultivating, defending, and deploying. Most studies of legitimacy in International Relations take the perspective of the ruling institution. In this article turn the tables and consider global legitimacy with an eye on political controversy and opposition: how do legitimacy studies look if we begin by assuming a gap between what the people want and what rulers want?

International organizations (IOs) are ubiquitous in international politics, in roles ranging from setting rules for governments and defining rights for individuals, to acting as settings for inter-state negotiations, to supplying some of the discursive concepts and resources taken up by governments and activists in domestic and international society. From landmines to bankruptcy law and beyond, there is compelling evidence of the practical influence of international institutions over the conditions of life for many people (on power politics see Lipscy 2017; on markets see Block-Lieb and Halliday 2017; more widely see Halliday and Shaffer 2015). International organizations sometimes exercise political authority over their subjects and as such they deserve the same kind of attention as is given to other governing institutions in society. Questions that one might ask about a government - is it transparent? it is accountable? to what ends does it deploy its authority? what follows from its governance and for whom? - are now increasingly also asked about IOs.

The essays in this collection advance these efforts by considering how legitimacy and legitimation affect IOs and how through them legitimacy shapes the broader world of international politics. The central premise of this approach is articulated by Tallberg and Zürn who say that "legitimacy is central for international organizations (IOs) to make a difference in world politics" (Tallberg and Zürn 2019, 1). From there, the contributions here consider how legitimacy can be measured, used in practice,

Ian Hurd

ianhurd@northwestern.edu

1 Northwestern University, Evanston, IL, USA 
manipulated, discussed, and undermined. Legitimacy is defined as belief in the rightful use of authority by an institution and it is operationalized as the observable behavior of either deference to the institution or opposition to it.

The contributions to this issue are united by an interest in putting legitimacy and legitimation in the foreground of conversations about global governance. They address legitimacy and legitimation with a diverse range of tools and in pursuit of different empirical questions. Nielson et al. (2019) try to understand what makes some elections monitoring organizations seem more legitimate than others by asking NGO workers for reactions to various scenarios. Schmidtke (2019) wonders about the opinions of 'elites' in Europe and the US regarding international organizations and parses media reporting on the UN, the EU, the G-8 and others for clues. Rocabert et al. (2019) see in the expansion of parliamentary organs among international organizations since the 1990s a strategic attempt by the governments that run them to legitimize the organization by boosting their procedural and deliberative credentials. Anderson et al. (2019) use experimental surveys to see how people respond to stylized changes in authority over climate policies, shifting from national to international governance agencies.

The collection opens fresh lines of inquiry in the field of international law and politics by bringing novel tools and questions to bear on global institutionalization. I take advantage of one of these openings to engage with the broad theme of the place of legitimacy in the politics of social order: I am interested in the political content that is revealed in debates about legitimacy, global governance, and international order. This is facilitated by the work of the contributors as they spell out models of how legitimacy works, how it is contested, and how it can be measured and studied with tools of social science.

Across their different empirical interests the essays here adopt a common intellectual framework for addressing legitimacy questions around global governance. I describe it below as a 'folk theory' and suggest that it has recently come to constitute a paradigm in IO studies. It relies on a kind of domestic analogy with roots in liberal political theory by drawing from research traditions that ask about how perceptions of legitimacy affect individuals' attitudes and behavior toward their own governments. I use the term 'folk theory' conscious of its more application in game-theory literature and intend it to indicate a proposition that is widely accepted and put to use to help explain things but that has not itself been proved.

My focus in this essay is on how contestation and opposition are modeled in relation to legitimacy and legitimation. The behavioralist study of legitimacy in global governance often infers the level of legitimation in an institution by assessing the degree of visible contestation around it: high legitimacy is predicted to produce low contestation; high compliance may be evidence of high legitimacy; heavy contestation is seen as a sign that the organization is lacking in legitimacy and may therefore find it harder to accomplish its goals. This complex of ideas uses the absence of protest as a proxy for the unobservable quality of legitimacy. It aims to be value-neutral by noting that subjects may seen an institution as legitimate in a sociological sense even if an outside observer finds it morally indefensible (Tallberg and Zürn 2019, 12). This builds a fence around the political content of legitimacy as a concept and makes it possible for outsiders to treat it as an objective fact (either subjects believe in its legitimacy or they do not) that has certain effects in society, amenable to analysis regarding its causes and effects and independent of any normative judgment about its worth or goodness. 
The analysis below shows how hard it is to maintain that fence in IR scholarship and point to its important political implications. It is common for legitimacy scholars to note that institutions work better when they are seen as legitimate. It is also common for studies of global governance to begin with the premise that contemporary global problems can only be addressed with collective efforts through international institutions. These two positions, independently but even more powerfully when put together, give global governance studies reason to see enhancing IO legitimacy as an important goal of IO scholarship. If global governance is the "best hope the world currently has" regarding our existential transnational challenges then it is politically imperative to strengthen global cooperation (Tharoor 2003). This casts those who disagree with an institution or its effects or decisions as obstacles to good governance. It is worth remembering that legitimation is a tool of social control. It is used by those in power to solidify their governance. The politics of legitimation look different from above and from below: to the governor, legitimation is a helpful device to lower the costs of governing; to the governed, it means acquiescing to rules that force you to do something you don't want to do. I am motivated in what follows by thinking about legitimation and IOs from the perspective of those on the bottom, whose agitation against the system is motivated by the sense that global rules are forcing them to bear costs while others gain the benefits. How do we study legitimacy and global governance differently if we have these people in mind rather than the IOs themselves?

\section{A folk theory of legitimacy}

Behind the study of global governance in the liberal institutionalist tradition sits a kind of conventional wisdom that ties together three features - legitimacy, compliance, and governance - in a particular way. This is the intellectual apparatus that binds the contributions to this special issue. Its logic goes like this: because IOs do not have the tools to coerce governments into following their rules, they must instead cultivate a belief in their appropriateness among those they aspire to govern. This belief is called legitimacy and the process by which it is created is legitimation (see also Chayes and Chayes 1996; Henkin 1979; Franck 1990; Hurd 2007; Coleman 2007; Ikenberry 2011). Legitimation leads actors to comply with the rules and decisions of the organization. When legitimacy is present, the subjects of an institution are inclined to respect or defer to it and by that respect they make choices which contribute to social order as defined by the organization. Delegitimation is the process or strategy of undermining this belief and leads to a decrease in support for the organization. It's both a crisis for the organization and a kind of release from the constraining effect of socialization upon beliefs about rightful authority.

Tallberg and Zürn (2019) neatly summarize this logic as they set out the premise of the research program. They join a long tradition of sociological research on legitimacy and legitimation in both domestic social theory and in international relations, from Weber on to today. The legitimacy model that they set out explains an outcome (i.e. acquiescence or support for an institution) with a causal variable (legitimacy) that generates the outcome but is itself unobservable. 
The causal relationship is widely assumed to be true and many scholars find it useful in making sense of empirical patterns as well as anomalies but the unobservable nature of the core concept is a central topic of discussion among legitimacy scholars from Max Weber through to now.

This set of ideas is a paradigm in the Kuhnian sense among global-governance scholars (Kuhn 1996). It sets out concepts and priors that define a field of study and that generate anomalies and questions that are the subject of research. The legitimacy paradigm accepts that there may be some rare occasions where IOs have the leverage to coerce governments into doing what they want. ${ }^{1}$ But it suggests that it is far more common that IOs cannot gain compliance through threats or side-payments and so they must rely on something else. IO scholars in this paradigm aim to explain the apparent anomaly of self-motivated compliance by self-interested sovereign actors. The folk theory of legitimacy explains this "something else." Legitimacy is an explanatory concept for observers and scholars as well as a practical resource for the organizations themselves. Legitimation changes the relation between individuals and the organization, from opposition to support, by affecting people's beliefs about authority. The substantive payoffs in the relation need not change; the only thing that needs to change are subjects' beliefs about whether the institution deserves their support or not.

This owes a lot - though perhaps not quite enough, as I discuss below - to Max Weber on authority, Talcott Parsons on "the problem of social order," and Tom Tyler on the psychology of rule-following (Weber 1978; Parsons 1939; Tyler 1990). It builds a bridge between classical liberal social contract theory, which asked how social order is possible given the "beastial aspects of the state of nature" ( $\mathrm{Ng} 2012$ referring to Thomas Hobbes) and contemporary state-centric global governance, which wonders how self-interested states manage the costs and dangers of their international interdependence. It has become a popular way for scholars of international relations and international law to chart a course through problems of international interdependence: it offers what looks like a consensual and cooperative path to the goal of global social order. It has a natural affinity with studies of courts, legal systems, and bureaucracies which are also confronted with the question of "how to get subjects to comply with rules for which there is little chance of enforcement?"2

The empirical essays take this starting point and use it to motivate their examination of the legitimation potential of particular entities or practices. Anderson, Bernauer, and Kachi adapt Tallberg and Zürn's approach to formulate tests for when people think that deferring to an organization is the appropriate course of action (2019). That deference, manifest as self-motivated compliance, is crucial to global governance because it makes it possible for IOs to exercise power without coercion. Rocabert and co-authors say that IOs "elicit higher compliance if they are perceived as legitimate by the participants and policy addressees" (Rocabert et al. 2019, 6). Schmidtke makes this clear when he notes that legitimation underpins "elites' support... [that] is important for the effectiveness of IOs" $(2019,34)$.

\footnotetext{
${ }^{1}$ The UN Security Council, for instance, sometimes has such power, as perhaps do international financial institutions or other agencies that can withhold resources as leverage over member-states.

${ }^{2}$ On legitimacy and international courts see Alter et al. 2018. On bureaucracy see Johnson and Urpelainen 2014. On legal orders in a diverse perspective see Halliday and Shaffer 2015.
} 


\section{The meaning of support \& the meaning of opposition}

The contributions to this issue examine the contestation that arises around legitimation as evidence that legitimation has not fully happened. Resistance to international organizations is seen as a reason to reconsider the institutional procedures (Anderson et al. 2019), deliberative bodies (Rocabert et al. 2019), and media presentation of international organizations (Schmidtke 2019). Where protests and opposition occur, the prescription is further investment in legitimation strategies. In this framing, protest and legitimacy are modeled as if they were in an antithetical relation with each other: the presence of opposition is a signal that the organization has not done enough legitimation; the absence of opposition is prima facia evidence that legitimation has been successful. An empirical prediction emerges as a corollary: if IOs were better legitimated then evidence of opposition would decrease. Schmidtke, for instance, says that "in times of contested multilateralism and rising populist nationalism [i.e. now]" IOs must attend carefully to the legitimacy beliefs among national elites $(2019,2)$. Failing to do so raises the likelihood that non-elites in society, who "rarely have welldeveloped attitudes toward IOs," will rise up to mobilize against them $(2019,2)$. For Schmidtke, global governance depends on "a modicum of positive legitimacy perceptions among their members and governance targets" and this is undermined if people especially elites - say negative things about IOs $(2019,2)$. This is both a normative and a conceptual framework: it begins with the conviction that global governance is desirable and then goes on to examine how its subjects can be convinced to act accordingly through media representations, socialization, and legitimation.

For Kuhn, paradigms are both limiting and empowering in research design: they help identify questions that can be answered by future research and at the same time they make some other questions seem to disappear. What is taken for granted defines what is asked and what isn't. The legitimacy paradigm defines a scope of research that includes the dynamics by which individuals are socialized to accept an institution as a rightful authority and excludes consideration of whether people feel that the institution helps or hurts their interests. It aims to distinguish between support that comes from believing in the rightful authority of the institution and support that comes from feeling that the organization helps one's life - and then it focuses scholarship on the former by designing research questions on legitimation that hold substantive politics constant. The research design encourages scholars to see contestation around IOs as a failure of legitimation rather than as evidence of substantive grievances over how power and wealth are apportioned, with the risk that legitimation is conceived as separate from, or an alternative to, politics.

The turn away from addressing the substantive effects of IOs is evident when Schmidtke suggests that the contestation around global governance - by which he means growing criticism of international organizations in public media - has undermined the legitimacy of international organizations $(2019,2)$. He goes on to identify the forces that affect discourses of legitimacy around international organizations and focuses on measurable features of the organization itself such as its bureaucratic structure and procedures and its performance against its professed goals, its degree of formal authority, and on cultural features of the society in general. Substantive disagreements over political choices and the distribution of gains are pushed out of the conversation in favor of attention to how people can be socialized to the rightfulness 
of the authority of the institutions. The discussion does not touch on the substantive political choices or tradoffs that come with global governance, or their effects on the lives, interests, and distributions of those affected by them.

The legitimacy paradigm aspires to a perspective on institutional legitimacy that is outside of politics in the sense of being independent of the substantive rules, stakes, struggles and interests that motivate political contestation in the real world, at least for the short-run moment that allows comparison of low- and high-legitimacy conditions. This apolitical perspective is not unusual in IR. It shares with appropriateness versus consequences debates of the 1990s the idea that is it possible to isolate support for an organization based on payoffs and welfare as opposed to a belief in its legitimacy and appropriateness. Schmidtke makes this explicit when he says that his goal is to craft a research design that can "distinguish genuine legitimacy assessments from mere expressions of 'specific' support grounded in individual cost-benefit calculations" $(2019,13)$. This has been described by Samantha Besson as a "content-independent" approach to international law and politics. It aims to understand the impact of institutions independent of the substantive content of their rules and decisions, as a means to see their power qua institutions (Besson 2011). Content-independent reasons for compliance with international law include its legitimacy, the strength of rule-of-law ideology, and a desire to be seen as a law-abiding actor.

This can be unhelpful in global governance studies to the extent it exiles questions about substantive payoffs from research about legitimation, and hides the sharp edge of governance. International political authority has power over the allocation of costs, benefits, and inequalities, and its legitimation is therefore crucial in the life chances of large numbers of people. It is particularly influential in places where governments are weak and international intervention is more likely. The exercise of governance always imposes costs on some and gives benefits to others and legitimation reinforces that distribution. Legitimation takes away some opposition to the authority and makes governing cheaper, along the lines that Steven Lukes' described as the third face of power. When global governance scholars aspire to enhance the legitimacy of international institutions, they become partisans on one side of a political struggle between individuals and authority. For this to be justifiable, one would want to know a great deal more about the actual impact of international organizations on people's lives in order to conclude that they deserve to be even more empowered over people than they are at present.

\section{What place for politics?}

The essays in this volume follow this intuition as they seek to understand compliance-through-legitimation as distinct from compliance-due-to-interests. As both an ontological and a methodological position, a 'legitimate organization' is one that people defer to for reasons other than their expectation that it will do good things for them and their world. The legitimacy paradigm identifies compliance in the absence of material interests as an anomaly and builds a research agenda to understand it. As a research program, it teaches that there is little to explain when people like, follow, or agree with rules and decisions that point in 
their favor and so compliance is interesting - as a practice or in theory - when it takes place in spite of interests rather than according to them.

Seeing this internal logic helps to reveal why the search for an non-political account of global governance legitimacy is destined to fail. Despite its best efforts, the paradigm cannot escape the fact that there is a substantive politics at the heart of the behaviors that form its dependent variable and also within the conceptual framework it uses to understand them. If the attraction of legitimacy both as a real-world quality of an IO and an analytic concept for scholars is that it produces support when self-interest would produce opposition then we already know something about the substantive politics hidden in the framework: the model assumes an antagonistic relationship between IOs and their subjects. Legitimation has a measurable effect in the sense sought by behavioralist methodologies only if the actors' position was not one of support. It is only from a starting point of indifference or hostility people can be socialized to endorse the institution. Socialization is irrelevant (that is: behaviorally un-measurable) if they already support it from the start.

In sum, if legitimation is a social force that induces compliance when interests do not, then the legitimacy paradigm in global governance hides a substantive politics by which global governance institutions are at odds with their subjects. Moments of resistance to international organizations - for instance, protests against UN peacekeepers in Haiti, legal claims against the World Bank in India, and anti-NATO protests in Chicago (Pillinger et al. 2016; EarthrightsInst 2018; Reynolds 2012) - come from disagreements about what should be done and by whom and about how costs and benefits will be allocated. All of this is certainly implicated with legitimacy and legitimation: unpopular policies are likely harder to legitimize, the powerful will seek to cement their advantages through legitimation, the weak will seek to mobilize against the legitimation done by the powerful, and so on. The politics of legitimation and delegitimation are steered by political motives and get their energy from different desires about how gains and losses will be allocated across interests.

That said, the original theory of legitimacy in the Weberian tradition, from which global governance studies get inspiration, is an account of how leaders gain support from followers. It takes the perspective of the governing institution or class and sees legitimation as one tool in a larger category of means of social control. The set also includes coercion, leadership, and inducement. Legitimacy is therefore one answer to the question of 'how to get subjects to go along with public authorities.' It is of interest to authorities because it promises to increase compliance and decrease opposition without having to make recourse to direct coercion or violence. When legitimation is successful, there is no sign of resistance to the authority because subjects have internalized its rightful status and see compliance as in their own interest. Rocabert et al. note that legitimation strategies are designed to make institutional authority more acceptable to its audience. As legitimacy goes up, opposition and resistance go down. Tallberg and Zürn say that legitimacy contributes "to IOs' ability to secure compliance with international rules." (2019, 3). Anderson, Bernauer, and Kachi see value in legitimacy for the global governance regime on climate change because it "set[s] the agenda in climate policy and inform[s] the initiatives launched at transnational, subnational and non-governmental levels" (2019, p.9). It is widely held that legitimation facilitates governance by reducing opposition and encouraging compliance. In the field of global governance studies this is assumed to be a good outcome - 'good' morally, 
politically, and substantively. But a wider perspective on power relations reminds us that what looks good to those in authority may not seem so great from below. It is worth examining more closely the assumption that increasing subordinates' compliance necessarily counts are progress.

Lindblom and Cohen coined the term "usable knowledge" to describe one kind of goal for social inquiry - practical insight that pays off for "social problem solving" (Lindblom and Cohen 1979). What counts as useful depends on the problems that one sees as standing in need of solving. The legitimacy paradigm interprets resistance to global governance institutions as a problem. As a solution, it suggests strategies of legitimation to improve the standing of the institution and socialize critics into supporters. It tells the institutions themselves that the answer to their unpopularity lies in redoubling their strategies of legitimation, and it teaches scholars to pay attention to legitimation strategies rather than to the substantive decisions and outcomes of the institutions itself. These are highly political lessons to come from the ostensibly apolitical legitimacy paradigm. Taken together they add up to something like the classic liberal internationalist ideology: the presumption that global affairs are best managed by transnational public institutions exercising authority upon the world (Jahn 2013; Ikenberry 2011). It makes a substantive argument for global political authority managed by the multilateral organizations of the twentieth century.

\section{Reconnecting politics and legitimation}

Legitimation uses the application of political forces to shape people's perceptions of their interests toward authority and thus to change their behavior. It increases acquiescence and reduces opposition ceteris paribus. This raises obvious questions about the politics going on in legitimacy and legitimation. To treat it as consensual is to miss its connection to politics and power. By valorizing compliance over opposition, governance via legitimation naturally sides with the governing authorities in any conflict with those over whom they exercise power. When scholarship their turns into advocacy for ways to legitimize global governance, it is not only taking sides in these contested politics but also taking the side of the dominant authority against the subjects.

One way forward it is to explicitly assume that global governance is indeed beyond politics. This is not a particularly robust position for reasons that should be obvious, but it is worth setting out in order to be explicit about one end of a continuum. It is a position that scholars sometimes fall back into without quite acknowledging it. For instance, if one thinks that global governance is on average pareto-improving over whatever is the prior condition, it might be possible to see it as defensible on the grounds that the winners outweigh the losers. This is analogous to how some economists defend international free trade: if the overall gains exceed the overall losses then the policy is desirable because in principle the winners could more than compensate the losers. The distributional effects might then be said to represent a separate research project, to be undertaken by others. Liberal institutionalists may make this argument for global governance. Barbara Koremenos for instance, speaking for one strand of rationalist analysis of IOs, suggests that international treaties are "rationally designed" to solve joint problems among states and their existence among consenting governments is evidence of their mutual desirability. Global governance she says "is as 
rationally designed for powerful states as it is for the less powerful" and "chosen in ways that increase the prospects for robustness of international cooperation" (Koremenos 2016, 21).

A more productive way would be to acknowledge the politics of global governance and include them at the center of the field. This requires paying close attention to winners and losers from international institutions. Rather than assume that global governance is good for all or that support for IOs can be understood without looking at payoffs, it is probably more realistic to begin with the assumption that whether one supports or opposes an international organization is closely related to whether or not that organization seems to be helping or hurting one's welfare. The conventional approach explicitly excludes the effect of payoffs as it looks for separate logics of consequences and appropriateness in behavior. I expect that this is meant by most IR scholars more as an analytic move than a substantive claim - but still the analytic model of legitimacy necessarily moves substantive politics away from center-stage.

The field of global governance studies is improved when we keep in mind that any form of governance will inevitably produce both winners and losers - and global governance is no different in this respect than other versions of rule or authority. The exercise of authority will necessarily impinge on the plans and interest of some while advancing others. Opposition to international organizations may well produce legitimation crises, but some major part of that opposition surely springs from the efforts of the losers trying to lose less and of the winners trying to hold on to their gains. This is a simple view and I suspect it is widely shared among scholars of international organizations - but it slips out of the legitimacy paradigm for the reasons have begun to set out in this essay.

The fraught politics of the International Criminal Court help illustrate the point. The ICC is rightly seen as a key piece of institutionalized global order and a potentially useful means for reducing atrocities. Its successes, failures, and controversies are well documented (Scheffer 2016). Some erstwhile supporters have recently turned hostile, adding to its political challenges (Vinjamuri 2016). Burundi withdrew in 2017; in 2018 the Philippines declared that it would do the same; in South Africa and Gambia, the threat of withdrawal has appeared as a tactic used by domestic political parties to activate some voters. One common complaint is the Court's heavy use in Africa relative to the rest of the world (Ssenyonjo 2017). Tallberg and Zürn are right to see in these developments a threat to the Court (2019). Seen through the lens of legitimacy, the solution to this problem might appear to lie in new strategies of legitimation. This is the view taken by the Canadian government, which has sought to strengthen the ICC by emphasizing its democratic qualities and its contribution to an international "rulesbased" order (Dion 2016). But this turns attention away from the substantive politics at the heart of the ICC's troubles. It might be that self-serving leaders are looking to avoid accountability for their own actions (as Stephen Rapp, US ambassador for war crimes, has said) or be a manifestation of the "structural defects in international humanism" and of the "endtimes" for the liberal-institutionalized version of "Human Rights" (as Stephen Hopgood suggests) - or it might be both (cf. Rapp cited in Chan and Simons 2016 with Hopgood 2013). But either way, the attempt to legitimate the ICC by reinforcing a rhetoric of universalism risks being more of a marketing strategy than an engagement with its substantive effects in the world. 
This is a familiar observation in discussions of the modes of political power, including Steven Lukes' third face of power (Lukes 2005. Also Barnett and Duvall 2005; Walters 2012). It is not new. But its importance is worth restating as IR scholars turn their attention to the politics around global institutions. It can be tempting to assume that global order springs from respect for global rules and thus to see anything that enhances compliance with the rules as naturally politically progressive. This fits with a Lockean liberal idea that multilateral rules represent a kind of social contract founded on freedom and consent at the international level. But the preference for compliance per se, absent any attention to the actual substance of the rules, makes for a depoliticized idea about the political framework of international institutions and practice that constitute the actually existing global order. The scope of possible research is truncated in a most awkward way: it dismisses all of the substance around the organization - that is, its contribution to the distribution of costs and benefits in society, its effects people, people's ideas about whether it serves their needs or not - and limits inquiry whatever remains after that is taken out.

\section{Rulers and ruled}

At stake here are competing views of the relation between the rulers and the governed. It is characteristic of liberals in IR and elsewhere to see legitimate rules as a progressive contribution to society, indeed perhaps as a prerequisite for society. They make it possible for individuals to use their freedom to engage in mutually beneficial acts of cooperation and undergird more complex possibilities for consensual and peaceful progress in society. Consent to the rules makes public authority legitimate and also generates self-motivated compliance. Legitimacy is central to liberal accounts of public governance as both a concept with which to understand society and a normative goal. But there is an authoritarian streak in this as well in that it endorses the state and other public authorities such as IOs in rule over their subjects. Opposition, to global governance or to the state, is diagnosed as a threat to good order which requires a response. Legitimacy theory offers legitimation as the appropriate response, such that the opponent might be socialized to support rather than oppose the governing institution. The protester appears insufficiently instructed as to the rightful authority of the organization and needs to be corrected. Opposition is deviant and compliance is normal. Dennis Wrong criticized this tendency in liberal social theory in his classic article in 1961 on the "oversocialized" conception of the person in sociology: if legitimation is conceived as a means by which society induces compliance from individuals, then a well-balanced subject should be expected to do nothing but comply. It creates a choice, Wrong said, in which "either someone has internalized the norms, or he is 'unsocialized,' a feral or socially isolated child, or a psychopath" (Wrong 1961, 188).

From the perspective of the organization, this is may make sense. Legitimation reduces the need to coerce subjects into compliance and, as Tallberg and Zürn say, "in general, legitimacy is a much cheaper means to secure compliance than coercion" $(2019,3)$. To the rulers, coercion and legitimacy are substitute goods. Both might get subjects to stop protesting. But the difference between the two is important as Max Weber long ago noted. The act of acquiescence does not reveal what is going on in the 
subject. It is quite possible for people to feel that a legitimate organization is behaving badly and so mobilize against it. They may accept an illegitimate organization because there is no other option if undermining it would leave them in an even worse position. They may tell an online poll that they disapprove of an international agreement institution as a way of expressing a wide range of political views. As Tallberg and Zürn note, it is important to think about the social meaning of acquiescence and its context in a web of power relations. With power and politics in mind, one might start to get a sense for how subjects understand the political authority they find around them and why they accept, ignore, or resist a given rule or institution.

Proponents of global governance maintain an enchanted view of actually existing IOs that sees them as inherently desirable in the pursuit of good governance on a global scale (Hurd 2016). It leads to the view that compliance with international rules amounts to good global citizenship, and resistance or opposition is regressive, anti-global, and anti-social. IR liberals and constructivists are particularly in danger of falling for this myth since they often find themselves defending international institutions as both a political and disciplinary imperative in the face of realist skepticism that institutions have meaningful political power.

Global governance studies can resist the temptation to celebrate its subject and should instead remain attentive to the specific political content of the rules and to the relations of power into which it is an intervention. This means that content-independent research design is unlikely to give insight into the politics of global institutions. A better path is to see global governance as governance, with winners and losers who are mobilized use the system to advance their goals, and who support or opposition to various rules, institutions, and rulers cannot be understood in isolation from how those forces affect their lives.

Any form of governance will redistribute gains and losses across society. Governance necessarily produces winners and losers. Global governance is no different in this respect from any model of domestic authority (Zürn 2018, 5). The legitimacy dynamics around international organizations are no doubt in part attributable to IOs' internal structure, media strategies, channels of participation and voice, and other features. But they are also certainly connected to how they affect the distribution of resources, power, and opportunities for people. This is not meant as criticism of global governance. It is instead a reminder that global governance is not politically neutral and isn't inherently desirable - its political valence is generated through action as it shapes the world in favor or some interests rather than others. International authority is thus similar to authority in other settings in that it encodes certain interests and advances some at the expense of others.

\section{Conclusion}

The essays in this issue treat legitimacy as a crucial contribution to IOs, and IOs as a crucial contribution to contemporary global order. They operate within a paradigm that sees the power and influence of IOs as in part a function of their legitimacy and use that framework to look for ways to identify, measure, and manipulate people's feelings of support for IOs. It manipulates both in the sense that it proposes ways to shape perceptions of IOs through legitimation strategies and also in the sense of deploying survey experiments that aim to change how people respond to survey questions by prompting them with different kinds of information. 
Legitimation in this approach is said to generate internally motivated compliance among people who might not comply in its absence. Its observable manifestation is acquiescence to rules and authority and the absence of contestation. I have highlighted here the danger that this conceptual framing of legitimacy may have a substantive side-effect of elevating rulefollowing to a position that privileges the views of those in power over those of the subjects. Recognizing this does not mean that we should not study legitimacy and legitimation in global governance - these are powerful social forces that shape the world and they are worth knowing. But we should keep in mind as well the inescapable political content of legitimacy as an explanation for rule-following. Because it mediates between rulers and subjects it is inseparable from whatever disagreements that arise between those two groups. Liberal social theory might teach that those conflicts are erased in a well-functioning society and in IR liberals might argue that consensual international institutions represent state-centric freewill in practice. But non-liberal theorists, from realists to Marxists to critical theorists, unite around the opinion that the liberal consensus is naïve and perhaps disingenuous. The nonliberal tradition of thought suggests that global governance is worth studying because it deploys political authority to settle disagreements over what should be done. Protests against aspects of global governance, whether they are the rules of tax havens, the terms of sovereign debt refinancing, or the immunities of UN peacekeepers, bring to mind more than just a failure of legitimation. They rest on substantive disagreements about how costs and benefits are distributed in global society. They arise from the fact that IOs impinge on people's interests, values, and ambitions in substantive ways.

Governance is a relation of power. It should be seen within the context of social contestation over who wins and who loses. It is neither apolitical nor neutral among outcomes nor an inherently progressive contribution to social order. Global governance, just like governance in any context, entails a world of nuance, trade-offs, distributional fights, and tragic choices. Legitimation is about getting people to believe that a given arrangement of these tradeoffs is appropriate. It entails the application of power in defense of the status quo. When it works, it causes opposition to disappear. Whether this is a good thing or not depends on how one feels about what is being disappeared.

Publisher's Note Springer Nature remains neutral with regard to jurisdictional claims in published maps and institutional affiliations.

\section{References}

Alter, K. J., Helfer, L. R., \& Madsen, M. R. (Eds.). (2018). The Authority of International Courts in a complex world. Oxford: Oxford University Press.

Anderson, B., Bernauer T., \& Kachi A. (2019). "Does international authority affect the perceived legitimacy of global governance?" Review of International Organizations, [this volume].

Barnett, M., \& Duvall R. (2005). "Power in global governance". In M. Barnett and R. Duvall eds. Power in global governance. Cambridge University Press.

Besson, S. (2011). "The legitimate Authority of International Human Rights”. In A. Føllesdal, J.K. Schaffer, and G. Ulfstein eds. The Legitimacy of International Human Rights Regimes. Cambridge University Press.

Chan, S., \& Simons M. (2016). "South Africa to Withdraw from International Criminal Court". New York Times, Oct. 21, p. A5.

Chayes, A., \& Chayes A.H. (1996). The new sovereignty: Compliance with international regulatory agreements. Harvard University Press.

Coleman, K. P. (2007). International organizations and peace enforcement: The politics of international legitimacy. Cambridge: Cambridge University Press. 
Dion, S. (2016). "Address by Min. Dion to the Canadian Council of International Law: Progress toward a Rules-Based Order, Not a Retreat.” http://news.gc.ca/web/article-en.do?nid=1148379.

Earthrights Institute. (2018). "Indian Fishing Community Asks U.S. Supreme Court to Hear Case Challenging World Bank Group Immunity," https://earthrights.org/media/indian-fishing-community-asks-u-ssupreme-court-hear-case-challenging-world-bank-group-immunity/.

Franck, T. M. (1990). The power of legitimacy among nations. Oxford: Oxford University Press.

Halliday, T. C., \& Shaffer, G. (Eds.). (2015). Transnational legal orders. Cambridge: Cambridge University Press. Henkin, L. (1979). How nations behave: Law and foreign policy. New York: Columbia University Press.

Hopgood, S. (2013). The Endtimes of human rights. Ithaca: Cornell University Press.

Hurd, I. (2007). After anarchy: Legitimacy and power in the UN security council. Princeton: Princeton University Press.

Hurd, I. (2016). Enchanted and disenchanted international law. Global Policy, 7(1), 96-101.

Ikenberry, G. J. (2011). Liberal leviathan: The origins, crisis, and transformation of American world order. Princeton: Princeton University Press.

Jahn, B. (2013). Liberal internationalism: Theory, history, practice (Palgrave Macmillan).

Johnson, T., \& Urpelainen, J. (2014). International bureaucrats and the formation of intergovernmental organizations: Institutional design discretion sweetens the pot. International Organization, 68(1), 177-209.

Koremenos, B. (2016). The continent of international law: Explaining agreement design. Cambridge: Cambridge University Press.

Kuhn, T. S. (1996). The Structure of Scientific Revolutions (3rd. ed.). Chicago: University of Chicago Press.

Lindblom, C. E., \& Cohen, D. K. (1979). Usable knowledge: Social science and social problem solving. New Haven: Yale University Press.

Lipscy, P. Y. (2017). Renegotiating world order: Institutional change and international relations. Cambridge: Cambridge University Press.

Lukes, S.M. (2005). Power: A radical view. Palgrave.

Ng, S. F. (2012). Hobbes and the Beastial body of sovereignty. In N. J. Hirschmann \& J. H. Wright (Eds.), Feminist interpretations of Thomas Hobbes. The Pennsylvania State University Press: University Park.

Nielson, D.L., S.D. Hyde and J. Kelley. (2019). "The Elusive Source of Legitimacy Beliefs: Civil Society Views of International Election Observers". Review of International Organizations [this volume].

Parsons, T. (1939). The structure of social action. New York: McGraw-Hill.

Pillinger, M., Hurd, I., \& Barnett, M. N. (2016). How to get away with cholera: The UN, Haiti, and international law. Perspectives on Politics, 14(1), 70-86.

Reynolds, D. (2012). “1000s protest the Chicago NATO summit”. CBSNews, May 20. https://www.cbsnews. com/news/1000s-protest-the-chicago-nato-summit/.

Rocabert, J., Schimmelfenning F., Crasnic L., and Winzen T. (2019). “The Rise of International Parliamentary Institutions: Purpose and Legitimation". Review of International Organizations [this volume].

Scheffer, D. J. (2016). Criminal Justice. In J. K. Cogan, I. Hurd, \& I. Johnstone (Eds.), Oxford handbook of international organizations. Oxford: Oxford University Press.

Schmidtke, H. (2019). "Elite Legitimation and Delegitimation of International Organizations in the Media: Patterns and Explorations". Review of International Organizations [this volume].

Ssenyonjo, M. (2017). "State Withdrawal Notifications from the Rome Statute of the International Criminal Court: South Africa, Burundi, and Gambi”. Criminal Law Forum (published online 13 June 2017).

Susan Block-Lieb and Terence C. Halliday. Forthcoming 2017. Global Legislators: How International Organizations Make Trade Law For The World. New York: Cambridge University Press.

Tallberg, J., \& Zürn M. (2019). The legitimacy and legitimation of international organizations: Introduction and framework. Review of International Organizations [this volume].

Tharoor, S. (2003) United Nations: It May Not Be Perfect, but It's the Best Hope the World Currently Has. The Independent, March 6.

Tyler, T. (1990). Why people obey the law. Princeton University Press.

Vinjamuri, L. (2016). The international criminal court and the paradox of authority. Law and Contemporary Problems, 79, 275-287.

Walters, W. (2012). Governmentality: Critical encounters. Routledge.

Weber, M. (1978). Economy and society: An outline of interpretive sociology (Vol. 2 vols). Berkeley: University of California Press.

Wrong, D. H. (1961). The Oversocialized conception of man in modern sociology. American Sociological Review, 26(2), 183-193.

Zürn, M. (2018). A theory of global governance: Authority, legitimacy, and contestation. Oxford University Press. 